\title{
Elephant grass silages with or without wilting, with cassava meal in silage production
}

\author{
Características da silagem de capim-elefante previamente emurchecido e aditivado com \\ farelo de mandioca
}

\author{
OLIVEIRA, Aline Cardoso ${ }^{1}$; GARCIA, Rasmo ${ }^{2}$; PIRES, Aureliano José Vieira ${ }^{3}$; \\ OLIVEIRA, Hellenn Cardoso ${ }^{3}$; ALMEIDA, Vitor Visintin Silva de ${ }^{1}$; OLIVEIRA, Ueslei \\ Leonardo Cardoso ${ }^{4}$; LIMA JÚNIOR, Dorgival Morais de ${ }^{1^{*}}$
}

\footnotetext{
${ }^{1}$ Universidade Federal de Alagoas, Campus Arapiraca, Maceió, Alagoas, Brasil.

${ }^{2}$ Universidade Federal de Viçosa, Departamento de Zootecnia, Viçosa, Minas Gerais, Brasil.

${ }^{3}$ Universidade Estadual do Sudoeste da Bahia, Departamento de Zootecnia, Vitoria da Conquista, Bahia, Brasil.

${ }^{4}$ Universidade Estadual de Santa Cruz, Ilhéus, Bahia, Brasil.

*Endereço para correspondência: juniorzootec@yahoo.com.br
}

\section{SUMMARY}

The experiment was developed to evaluate the effects of wilting and inclusion of cassava meal level on nutritive value, fermentative characteristics and losses of elephant grass silage. The $4 \times 2$ factorial scheme was adopted, with four repetitions, in a completely randomized design. The factors evaluated were wilting (without and with) and cassava meal level $(0$; $7.5 ; 15$ and $22.5 \%$ of natural matter, DN). PVC silos with $50 \mathrm{~cm}$ height and $10 \mathrm{~cm}$ diameter were used for silages production, which were opened after 60 days. The wilting and cassava meal addition had increasing linear effect on DM content. Silages with cassava meal showed reduction of total nitrogen, ether extract, acid detergent insoluble nitrogen, neutral detergent fiber ash and protein free, acid detergent fiber, celluloses, hemicelluloses and lignin contents and increase of organic matter content, DM in vitro digestibility and total digestible nutrients. Relative to variables inherent to silages' fermentative characteristics, $\mathrm{pH}$ presented quadratic behavior. Concerning to ammonia nitrogen, it was observed quadratic and decreasing linear behavior for silages without and with wilting, respectively. Wilting and cassava meal inclusion provided smaller effluent losses.

Keywords: by-product, bromatologic composition, effluent, digestibility, Pennisetum purpureum

\section{RESUMO}

O experimento foi desenvolvido para avaliar os efeitos do emurchecimento e da inclusão de níveis de farelo de mandioca sobre o valor nutritivo, as características fermentativas e as perdas por gases e efluente da silagem de capim-elefante. Foi adotado o esquema fatorial $4 \times 2$, com quatro repetições, no delineamento inteiramente casualizado. Os fatores avaliados foram níveis de farelo de mandioca $(0 ; 7,5 ; 15$ e $22,5 \%$ da matéria natural, MN) e emurchecimento (com e sem). Foram usados silos de PVC, com $50 \mathrm{~cm}$ de altura e $10 \mathrm{~cm}$ de diâmetro para a produção das silagens, que foram abertos após 60 dias. O emurchecimento e a adição do farelo de mandioca tiveram efeito linear crescente sobre o teor de matéria seca (MS). As silagens com farelo de mandioca apresentaram redução dos teores de nitrogênio total, extrato etéreo, nitrogênio insolúvel em detergente ácido, fibra em detergente neutro isenta de cinzas e proteína, fibra em detergente ácido, celulose, hemicelulose e lignina e elevação do teor de matéria orgânica, da digestibilidade in vitro da MS e dos nutrientes digestíveis totais. No que concerne às características fermentativas das silagens, o $\mathrm{pH}$ apresentou comportamento quadrático. Quanto ao nitrogênio amoniacal, observou-se comportamento quadrático e linear decrescente para as silagens sem e com emurchecimento, respectivamente. $\mathrm{O}$ emurchecimento e a inclusão do farelo de mandioca propiciaram menores perdas por efluente. $\mathrm{O}$ emurchecimento e a adição 
de farelo de mandioca melhora o valor nutritivo e as características fermentativas das silagens estudadas.

Palavras-chave: composição bromatológica, coproduto da mandioca, digestibilidade, efluente, Pennisetum purpureum

\section{INTRODUCTION}

Among the non-grain grasses used in silage production, the elephant grass (Pennisetum purpureum) stands out as a forage with an excellent potential for dry matter production (DM) (54 tons /MS/ hectare) and with a high amount of soluble carbohydrates $(4.1-13.8 \%$ in DM) (SANTOS et al., 2013) when compared to Panicum (2.8-3.8 \%), Brachiaria (3.1-4.5\%), and Cenchrus (2.3-3.1 \%) - (PINHO et al., 2013, RIGUEIRA et al., 2013).

Although it has a high content of soluble carbohydrates, the use of elephant grass for silage production is limited due to the high moisture content (16-20\%) and high buffer capacity of this grass (ZANINE et al., 2010). The high moisture content can result in undesirable fermentations of the ensiled mass as well as promote losses of the soluble nutritive components through effluents (DUNIÈRE et al., 2013).

The limitations of elephant grass silage may be partially controlled by increasing the DM percentage of the grass by both wilting and the application of moisture absorbers (OLIVEIRA et al., 2012; GEBREHANNA et al., 2014). From a practical point of view, wilting is only viable in areas where grass harvesting can not be mechanized as in small properties or in areas with irregular topography.

Regarding the use of absorber additives in grass silages, the dehydrated byproducts of the cassava processing present characteristics that can benefit the final quality of the silage, due to their high DM content, which could contribute to the elevation of the silage $\mathrm{DM}$ and, as a consequence, would reduce the losses of nutritive value by effluent. Besides, they are a highly energetic source with carbohydrates of fast fermentation in the rumen (DÓREA et al., 2013; GONÇALVES et al., 2014; NAPASIRTH et al., 2015).

Therefore, this study aimed to determine the nutritive value, fermentative characteristics and losses by gas and effluents from elephant grass silage with and without wilting, with increasing levels of cassava meal.

\section{MATERIALS E METHODS}

The elephant grass (Pennisetum purpureum, Schum. Cv. Napier) was obtained from a grassland established in a MTo (Typic Haplustoll), semideciduous forest and hilly relief phase (EMBRAPA, 2006), belonging to the State University of Southwestern Bahia, UESB, Itapetinga, BA, cut at 60 days of regrowth.

The experiment was performed in a completely randomized design, with a 4 x 2 factorial scheme, with four levels of cassava meal $(0 ; 7.5 ; 15$ e $22.5 \% \mathrm{NM})$ with and without wilting, with four replicates.

The cassava meal came from flour houses of rural communities located in Vitória da Conquista-BA. The meal is originated from the material discarded from the cloths or deposition channels of the starch milk from the washing of the ground cassava.

The material was cut in a regulated ensiling into pieces of approximately 2 $\mathrm{cm}$. In the wilting process, the grass was harvested and scattered in the field and, 
after 8 hours of sun exposure, was cut and added to the cassava meal and ensiling. The cassava meal without wilting was incorporated after the grass cutting, and the proportion was added based on the natural matter of the grass.
The chemical-bromatological composition of the cassava meal (CM) and of the elephant grass, with and without wilting can be observed in Table 1 .

Table 1. Chemical composition, $\mathrm{pH}$ and in vitro digestibility of dry matter (IVDDM) of elephant grass and cassava meal

\begin{tabular}{|c|c|c|c|}
\hline \multirow{2}{*}{ Item } & \multicolumn{2}{|c|}{$\begin{array}{l}\text { Elephant grass } \\
\end{array}$} & \multirow{2}{*}{ Cassava meal } \\
\hline & Without wilting & With wilting & \\
\hline Dry matter & 19.5 & 30.0 & 85.1 \\
\hline Organic Matter $^{1}$ & 91.0 & 91.6 & 98.6 \\
\hline Crude protein ${ }^{1}$ & 5.4 & 4.4 & 2.8 \\
\hline Ethereal extract ${ }^{1}$ & 1.3 & 1,8 & 0.46 \\
\hline $\mathrm{NDF}^{1^{*}}$ & 71.9 & 69.5 & 16.3 \\
\hline $\mathrm{NDFAP}^{1^{*}}$ & 66.8 & 65.8 & 12.5 \\
\hline $\mathrm{ADF}^{1^{*}}$ & 48.2 & 50.0 & 8.6 \\
\hline $\operatorname{Ash}^{1}$ & 9.0 & 8.4 & 1.4 \\
\hline Lignin $^{1}$ & 6.4 & 6.8 & 0.86 \\
\hline Cellulose $^{1}$ & 35.5 & 38.5 & 6.7 \\
\hline Hemicellulose $^{1}$ & 23.7 & 19.4 & 7.6 \\
\hline $\mathrm{NDIN}^{1^{*}}$ & 0.21 & 0.24 & 0.12 \\
\hline $\mathrm{ADIN}^{1 *}$ & 0.16 & 0.17 & 0.10 \\
\hline $\mathrm{NIDN}^{2 *}$ & 24.3 & 34.1 & 26.8 \\
\hline $\mathrm{NIDA}^{2^{*}}$ & 18.5 & 24.1 & 22.3 \\
\hline $\mathrm{CHO}^{1^{*}}$ & 84.3 & 85.4 & 95.3 \\
\hline $\mathrm{NFC}^{1^{*}}$ & 17.5 & 19.6 & 82.8 \\
\hline $\mathrm{pH}$ & 5.5 & 5.31 & - \\
\hline IVDDM $^{1 *}$ & 69.6 & 67.6 & 99.0 \\
\hline
\end{tabular}

After mixing the amount of cassava meal, the material was stored for 60 days in PVC silos, $50 \mathrm{~cm}$ high and $10 \mathrm{~cm}$ of diameter, with Bunsen valve to release the gases from the fermentation.

One kilo of sand was placed at the bottom of each silo, separated from the forage by a thin plastic cover to capture the effluent from the forage silage.

In the silo, $1,900 \mathrm{~g}$ of the mixture (additive plus elephant grass) were allocated and compressed, obtaining a specific mass of $600 \mathrm{~kg} / \mathrm{m}^{3} \mathrm{NM}$.
Silo + lid + dry sand + plastic cover were weighed and then, full and sealed to the quantitative determination of gas losses, dry matter recovery (DMR) and effluent losses, based on gravimetric differences. After 60 days, the silo + lid + sand + plastic cover + silage was weighed again and later the silage was removed to weigh only the silo + sand + plastic cover.

The silages losses in the form of gases and effluent and dry matter recovery were quantified by weight difference, through equations adapted from Santos et al (2008). 
Gas losses were calculated according to the equation: Gases $=(\mathrm{FWi}-\mathrm{FWf}) /(\mathrm{CMi}$ $\times \mathrm{DMi}) \times 100$, where $\mathrm{FWi}=$ the full silo weight after sealing $(\mathrm{kg})$; FWf $=$ the full silo weight after opening (kg); $\mathrm{CMi}=$ the fodder mass after sealing $(\mathrm{kg})$ and $\mathrm{DMi}=$ the fodder dry mass content after sealing. Effluent losses were calculated by the equation below, based on the difference on weight of the sand and related to the mass of fresh matter (CM) at sealing:

Effluents $=([\mathrm{EWf}-\mathrm{TS}]-[\mathrm{EWi}-$ $\mathrm{TS}]) / \mathrm{CMi} \times 100$, where $\mathrm{E}=$ the effluent production ( $\mathrm{kg}$ per $100 \mathrm{~kg}$ of MV); EWf $=$ the weight of the empty silo plus sand after opening $(\mathrm{kg})$; $\mathrm{TS}=$ the tare of the silo; $\mathrm{EWi}=$ the weight of the empty silo plus sand after sealing $(\mathrm{kg})$; $\mathrm{TS}=$ the tare of the silo and $\mathrm{CMi}=$ the fodder mass after sealing (kg) - (SANTOS et al., 2008).

The following equation was used to estimate the dry matter recovery:

DMR $(\%)=([$ GMfo $\times$ DMfo $] /[$ SMi $x$ DMsi] $) \times 100$, where GMfo is the fodder green mass $(\mathrm{kg})$ at the moment of ensilage; DMfo is the fodder dry mass (\%) at the moment of ensilage; SMi is the silage mass $(\mathrm{kg})$ after opening the silos and DMsi is the silage dry matter (\%) after opening the silos (SANTOS et al., 2008).

After the period of 60 days, the silos were opened, and samples were collected and frozen for further analysis.

Part of the samples were thawed at room temperature, packed in a paper bag and taken to the pre-drying oven for 72 hours at $65^{\circ} \mathrm{C}$. Afterwards, they were ground in a Willey-type mill with a $1 \mathrm{~mm}$ mesh sieve and subjected to chemicalbromatological analysis [Dry matter (DM); Ash; Ethereal extract (EE); Total nitrogen $(\mathrm{TN})$; Neutral detergent fiber (NDF); Neutral detergent fiber corrected for ash and protein (NDFap); Acid detergent fiber (ADF); Lignin; Nitrogen insoluble in neutral detergent (NIND);
Nitrogen insoluble in acid detergent (NIAD); Total Carbohydrates (CHO); Non-fibrous carbohydrates (NFC))] and in vitro dry matter digestibility (IVDMD) according to the methodologies described by Silva \& Queiroz (2002) and total digestible nutrients (TDN), according to the methodology proposed by Weiss et al. (1992), with modifications suggested by the NRC (2001).

The analyzes of neutral detergent (NDF) and acid detergent fiber (ADF) (VAN SOEST et al., 1991) were autoclaved according to Pell \& Schofield (1993).

Part of the silage (in natura) $(50 \mathrm{~g})$ was triturated with $200 \mathrm{~mL}$ of water in an industrial blender and gauze filtered to extract the aqueous medium, which was used for analysis of ammoniacal nitrogen $(\mathrm{N}-\mathrm{NH} 3)$ and $\mathrm{pH}$. The N-NH3 content, as a percentage of total $\mathrm{N}$, was measured using magnesium oxide and calcium chloride, according to Cunniff (1995).

The data were interpreted through analysis of variance, regression study by orthogonal polynomials for the quantitative factor, referring to the levels of cassava meal added in elephant grass silage, and application of $\mathrm{F}$ test to the qualitative factor, referring to wilting (with and without wilting), and the evaluation of possible interactions between these factors. In the regression study using orthogonal polynomials, the significance, the coefficients of determination and the behavior observed for the variable were considered. The significance level of $5 \%$ probability was adopted using the Statistical Analysis System (SAS, 1999).

\section{RESULTS AND DISCUSSION}

There was wilting $\mathrm{x}$ cassava meal levels interaction $(\mathrm{P}<0.05)$ for the variables dry matter (DM), total nitrogen (TN), acid 
detergent insoluble nitrogen (ADIN) and in vitro DM digestibility (IVDDM). Evaluating the effect of wilting within cassava meal levels, higher levels of DM $(\mathrm{P}<0.05)$ were observed in the wilted silage at all levels (Table 2).

The DM contents of the silages were increased by 0.2 and 0.3 percentage units to each gram of cassava meal added to the elephant grass without and with wilting, respectively. The linear increase of DM with the addition of cassava meal is due to the higher DM content of the byproduct in relation to elephant grass.

Table 2. Chemical composition and in vitro digestibility of DM (IVDDM) of elephantgrass ensiled with and without wilting with different levels of cassava meal $(\mathrm{CM})$

\begin{tabular}{|c|c|c|c|c|c|c|c|}
\hline \multirow{2}{*}{ Wilting } & \multicolumn{4}{|c|}{ Cssava meal (\% NM) } & \multirow{2}{*}{ Mean } & \multirow{2}{*}{ CV $(\%)$} & \multirow{2}{*}{$\begin{array}{c}\text { Regression } \\
\text { equation }\end{array}$} \\
\hline & 0.0 & 7.5 & 15.0 & 22.5 & & & \\
\hline \multicolumn{8}{|c|}{ DM (\% NM) } \\
\hline Without & $21.1^{b}$ & $22.0^{b}$ & $23.8^{b}$ & $26.6^{b}$ & 23.4 & \multirow{2}{*}{2.0} & 1 \\
\hline With & $24.8^{\mathrm{a}}$ & $27.5^{\mathrm{a}}$ & $29.1^{\mathrm{a}}$ & $31.8^{\mathrm{a}}$ & 28.3 & & 2 \\
\hline & 22.9 & 24.7 & 26.5 & 29.2 & - & - & - \\
\hline \multicolumn{8}{|c|}{ OM (\% DM) } \\
\hline Without & 89.8 & 91.2 & 92.2 & 93.0 & $91.5^{\mathrm{a}}$ & \multirow{2}{*}{0,5} & \multirow{2}{*}{3} \\
\hline With & 90.4 & 91.5 & 92.4 & 93.0 & $91.7^{\mathrm{a}}$ & & \\
\hline Mean & 90.1 & 91.3 & 92.3 & 93.0 & - & - & - \\
\hline \multicolumn{8}{|c|}{$\mathrm{EE}(\% \mathrm{DM})$} \\
\hline Without & 3.3 & 3.2 & 2.9 & 2.5 & $3.0 \mathrm{a}$ & \multirow{2}{*}{8,6} & \multirow{2}{*}{4} \\
\hline With & 3.0 & 3.2 & 2.6 & 2.8 & $2.9^{\mathrm{a}}$ & & \\
\hline Mean & 3.15 & 3.2 & 2.8 & 2.7 & - & - & - \\
\hline \multicolumn{8}{|c|}{$\mathrm{TN}(\% \mathrm{DM})$} \\
\hline Without & $1.11^{b}$ & $1.26^{\mathrm{a}}$ & $1.19^{\mathrm{a}}$ & $1.16^{\mathrm{a}}$ & 1.18 & \multirow{2}{*}{6,7} & 5 \\
\hline With & $1.26^{\mathrm{a}}$ & $1.19^{\mathrm{a}}$ & $1.13^{\mathrm{a}}$ & $1.11^{\mathrm{a}}$ & 1.17 & & 6 \\
\hline Mean & 1.19 & 1.22 & 1.16 & 1.13 & - & - & - \\
\hline \multicolumn{8}{|c|}{ NIND (\% MS) } \\
\hline Without & 0.13 & 0.13 & 0.12 & 0.12 & $0.13^{\mathrm{a}}$ & \multirow{2}{*}{7,9} & \multirow{2}{*}{7} \\
\hline With & 0.11 & 0.12 & 0.11 & 0.12 & $0.12^{b}$ & & \\
\hline Mean & 0.12 & 0.13 & 0.12 & 0.12 & - & - & - \\
\hline \multicolumn{8}{|c|}{ NIAD (\% MS) } \\
\hline Without & $0.10^{\mathrm{a}}$ & $0.09^{\mathrm{a}}$ & $0.08^{\mathrm{a}}$ & $0.08^{b}$ & 0.09 & \multirow{2}{*}{12,1} & 8 \\
\hline With & $0.11^{\mathrm{a}}$ & $0.08^{\mathrm{a}}$ & $0.08^{\mathrm{a}}$ & $0.11^{\mathrm{a}}$ & 0.10 & & 9 \\
\hline Mean & 0.10 & 0.09 & 0.08 & 0.09 & - & - & - \\
\hline \multicolumn{8}{|c|}{ TDN (\% MS) } \\
\hline Without & 51.0 & 54.7 & 58.6 & 60.7 & $56,2^{\mathrm{a}}$ & \multirow{2}{*}{1,8} & \multirow{2}{*}{10} \\
\hline With & 51.0 & 54.8 & 57.5 & 59.9 & $56,0^{\mathrm{a}}$ & & \\
\hline Mean & 51.0 & 54.8 & 58.0 & 60.3 & - & - & - \\
\hline \multicolumn{8}{|c|}{ IVDDM (\%) } \\
\hline Without & $66.7^{\mathrm{a}}$ & $72.5^{\mathrm{a}}$ & $75.8^{\mathrm{a}}$ & $79.5^{\mathrm{a}}$ & 74.0 & \multirow{2}{*}{2.0} & 11 \\
\hline With & $67.8^{\mathrm{a}}$ & $71.2^{\mathrm{a}}$ & $71.7^{\mathrm{b}}$ & $77.0^{\mathrm{b}}$ & 72.0 & & 12 \\
\hline Mean & 67.3 & 71.8 & 73.7 & 78.2 & - & - & - \\
\hline
\end{tabular}

Means followed by the same letter in the same column do not differ from each other by the F-test at $5 \%$ probability; $\hat{\mathrm{Y}}^{1}=20,6069+0,2474 \mathrm{CM}\left(\mathrm{r}^{2}=0,95\right) ; \hat{\mathrm{Y}}^{2}=24,8933+0,3007 \mathrm{CM}\left(\mathrm{r}^{2}=0,99\right) ; \hat{\mathrm{Y}}^{3}=90,2462$ $+0,1261 \mathrm{CM}\left(\mathrm{r}^{2}=0,98\right) ; \hat{\mathrm{Y}}^{4}=3,2172-0,0238 \mathrm{CM}\left(\mathrm{r}^{2}=0,99\right) ; \hat{\mathrm{Y}}^{5}=1,18 ; \hat{\mathrm{Y}}^{6}=1,2537-0,0068 \mathrm{CM}\left(\mathrm{r}^{2}\right.$ $=0,94) ; \hat{\mathrm{Y}}^{7}=0,12 ; \hat{\mathrm{Y}}^{8}=0,1030-0,0011 \mathrm{CM}\left(\mathrm{r}^{2}=0,92\right) ; \hat{\mathrm{Y}}^{9}=0,1072-0,0048 \mathrm{CM}+0,0002 \mathrm{CM}^{2}\left(\mathrm{r}^{2}=\right.$ $0,99) ; \hat{\mathrm{Y}}^{10}=51,4230+0,4133 \mathrm{CM}\left(\mathrm{r}^{2}=0,98\right) ; \hat{\mathrm{Y}}^{11}=67,4009+0,5537 \mathrm{CM}\left(\mathrm{r}^{2}=0,98\right) ; \hat{\mathrm{Y}}^{12}=67,6917+$ $0,3728 \mathrm{CM}\left(\mathrm{r}^{2}=0,98\right)$. 
Andrade et al. (2010) evaluated absorbent additives in elephant grass silage and verified an increase of $0.5 ; 0.5$ and 0.6 percentage units in the dry matter of the silage when they were added with cassava meal, cocoa shell and cocoa meal, respectively. The DM values found in the wilting silages ranged from 24.8 to 31.8 $\%$, showing the absorbance potential of the cassava meal.

For the variables $\mathrm{OM}$ and $\mathrm{EE}$, the analysis of variance revealed only effect $(\mathrm{P}<0.05)$ of the cassava meal. The addition of cassava meal increased OM values linearly, adding $0.12 \%$ for each unit of cassava meal added (Table 2). This behavior can be explained by the low contents of ash cassava meal $(1.4 \%$ $\mathrm{DM})$, compared to elephant grass $(8.7 \%$ $\mathrm{DM})$, which resulted in an increase in OM content in silages.

Regarding the EE levels, the regression analysis revealed a linear decreasing behavior $(\mathrm{P}<0.05)$, estimating a reduction of 0.02 percentage unit for each unit of cassava meal added (Table 2 ), due to the low levels of the residue used. Maza et al. (2011) also observed decreasing linear effect $((\hat{\mathrm{Y}}=2,221$ $\left.0,0079 \mathrm{X} ; \mathrm{r}^{2}=0,42\right)$ of ethereal extract of elephant grass silages over the addition of cassava root.

There was significant interaction $(\mathrm{P}<0.05)$ between wilting and cassava meal levels, for NT and NIAD variables. For NIND, the analysis of variance revealed only a wilting effect $(\mathrm{P}<0.05)$.

When analyzing the wilting effect within the levels of cassava meal, TN values were higher $(\mathrm{P}<0.05)$ for the wilted silage without cassava meal. Regarding the wilting silage over the levels of cassava meal, a reduction of $0.006 \%$ per unit of cassava meal added was estimated (Table 2). This behavior was already expected, due to the low CP values of cassava meal $(2.8 \%$ DM $)$ compared to elephant grass $(5.4 \% \mathrm{DM})$, which had a dilution effect. These results corroborrate with those obtained by Zanine et al. (2010), who also verified reduced $\mathrm{TN}$ content by increasing the inclusion of cassava scrap levels in elephant grass silage.

It is known that the $\mathrm{TN}$ content of the ruminant diet has an effect on the production of microbial protein in the rumen. It is recommended a minimum of $1 \% \mathrm{TN}, 7 \% \mathrm{CP}$ or $5-10 \mathrm{mg}$ of ammoniacal $\mathrm{N} / 100 \mathrm{~mL}$ of ruminal liquid (BACH et al., 2005). Considering the values observed in this study, the silages presented levels of $\mathrm{TN}$ in the limit to guarantee microbial synthesis, therefore, caution is recommended in the use of silages as exclusive food in animals of high nutritional requirement.

The NIND content presented a mean of $0.12 \% \mathrm{DM}$ and did not differ $(\mathrm{P}>0.05)$ with the inclusion levels of cassava meal or wilting.

Evaluating the wilting effect within cassava meal levels, a difference $(\mathrm{P}<0.05)$ in NIAD contents was observed only at the level of $22.5 \%$ of cassava meal for the silages without and with wilting (Table 2). With respect to NIAD contents as a function of cassava meal levels, the regression analysis revealed, for non-wilting silage, a linear decreasing behavior of $0.0011 \%$ for each unit of cassava meal added. With respect to wilting silage, a quadratic behavior was observed, with a minimum point of 0.0784 in the dose of $12 \%$ inclusion of cassava meal (Table 2).

For the total digestible nutrients (TDN), only the cassava meal effect $(\mathrm{P}<0.05)$ was observed, with an increasing linear behavior with the addition of cassava meal. It is estimated increments of $0.4 \%$ for each unit of cassava meal added (Table 2). The cassava agroindustrial residues present high energy value, which certainly contributed to the increase of the TDN in the silages 
(ODUGUWA et al., 2013; SILVA et al., 2013).

The in vitro digestibility of MS (IVDMD) presented significant interaction $(\mathrm{P}<0.05)$. Analyzing the wilting effect within the CM levels, a difference $(\mathrm{P}<0.05)$ can only be verified for 15 and $22.5 \%$ of cassava meal, in which the silages without wilting presented higher values (Table 2). Considering only the levels of inclusion of cassava meal in elephant grass, the IVDMD of the silages presented, through the regression analysis, increasing linear behavior, being attributed an increase of 0.55 and 0.37 percentage units in the aforementioned variable for each unit of cassava meal added to the silages without and with wilting, respectively. Probably, the increase in IVDMD is due to the high digestibility value of DM (99\%) and low ADF content $(8.6 \% \mathrm{DM})$ of the residue used. Dórea et al. (2013) observed that the inclusion of cassava scraping to elephantgrass silages promoted increased rumen degradation of the fiber, contributing to an increase in IVDMD.

Significant interaction $(\mathrm{P}<0.05)$ was observed for the variables NDFap, ADF and cellulose. Evaluating the wilting effect within the levels of manioc cassava meal, lower values of NDF and $\mathrm{CP}$ were observed in the non-wilted silages, with 15 and $22.5 \%$ of meal (Table 3).

Table 3. Fibrous fraction of elephant grass ensiled with and without wilting and cassava meal $(\mathrm{CM})$

\begin{tabular}{|c|c|c|c|c|c|c|c|}
\hline \multirow{2}{*}{ Wilting } & \multicolumn{4}{|c|}{ Cassava meal (\% NM) } & \multirow{2}{*}{ Mean } & \multirow{2}{*}{ CV $(\%)$} & \multirow{2}{*}{ Regression equation } \\
\hline & 0,0 & 7,5 & 15,0 & 22,5 & & & \\
\hline \multicolumn{8}{|c|}{ NDFap (\% MS) } \\
\hline Without & $70,7^{\mathrm{a}}$ & $61,7^{\mathrm{a}}$ & $52,6^{b}$ & $46,9^{b}$ & 51,0 & \multirow{3}{*}{1,66} & 1 \\
\hline With & $70,8^{\mathrm{a}}$ & $62,0^{\mathrm{a}}$ & $57,1^{\mathrm{a}}$ & $51,1^{\mathrm{a}}$ & 60,3 & & 2 \\
\hline Mean & 70,8 & 61,8 & 54,9 & 49,0 & & & \\
\hline \multicolumn{8}{|c|}{ ADF (\% MS) } \\
\hline Without & $46,9^{\mathrm{a}}$ & $40,2^{\mathrm{a}}$ & $35,4^{b}$ & $30,7^{b}$ & 38,3 & \multirow{3}{*}{3,01} & 3 \\
\hline With & $46,5^{\mathrm{a}}$ & $41,8^{\mathrm{a}}$ & $38,8^{\mathrm{a}}$ & $36,7^{\mathrm{a}}$ & 40,9 & & 4 \\
\hline Mean & 46,7 & 40,9 & 37,1 & 33,7 & & & \\
\hline \multicolumn{8}{|c|}{ Cellulose (\% MS) } \\
\hline Without & $40,2^{\mathrm{a}}$ & $32,2^{\mathrm{a}}$ & $25,8^{\mathrm{a}}$ & $25,7^{\mathrm{a}}$ & $30,9^{\mathrm{a}}$ & \multirow{3}{*}{7,76} & 5 \\
\hline With & $33,5^{\mathrm{b}}$ & $34,9^{\mathrm{a}}$ & $28,9^{\mathrm{a}}$ & $25,5^{\mathrm{a}}$ & $30,7^{\mathrm{a}}$ & & 6 \\
\hline Mean & 36,9 & 33,5 & 27,4 & 25,6 & & & \\
\hline \multicolumn{8}{|c|}{ Hemicellulose (\% MS) } \\
\hline Without & 28,6 & 26,1 & 21,5 & 20,1 & $24,1^{\mathrm{a}}$ & \multirow{3}{*}{5,6} & \multirow{3}{*}{7} \\
\hline With & 28,6 & 24,5 & 22,5 & 18,1 & $23,4^{\mathrm{a}}$ & & \\
\hline Mean & 28,6 & 25,3 & 22,0 & 19,1 & & & \\
\hline \multicolumn{8}{|c|}{ Lignin (\% MS) } \\
\hline Without & 5,9 & 4,8 & 4,3 & 4,3 & $4,8^{\mathrm{a}}$ & \multirow{3}{*}{13,0} & \multirow{3}{*}{8} \\
\hline With & 5,2 & 5,3 & 4,5 & 4,4 & $4,9^{\mathrm{a}}$ & & \\
\hline Mean & 5,5 & 5,0 & 4,4 & 4,3 & & & \\
\hline \multicolumn{8}{|c|}{$\begin{array}{l}\text { Means followed by the same letter in the same column do not differ from each other by the F-test at 5\% } \\
\text { probability; } \hat{\mathrm{Y}}^{1}=70,1021-1,073817 \mathrm{CM}\left(\mathrm{r}^{2}=0,99\right) ; \hat{\mathrm{Y}}^{2}=69,8887-0,853094 \mathrm{CM}\left(\mathrm{r}^{2}=0,98\right) ; \hat{\mathrm{Y}}^{3}= \\
46,3330-0,711386 \mathrm{CM}\left(\mathrm{r}^{2}=0,99\right) ; \hat{\mathrm{Y}}^{4}=45,7857-0,429883 \mathrm{CM}\left(\mathrm{r}^{2}=0,96\right) ; \hat{\mathrm{Y}}^{5}=40,4126- \\
1,44578 \mathrm{CM}+0,0346685 \mathrm{CM}^{2}\left(\mathrm{r}^{2}=0,99\right) ; \hat{\mathrm{Y}}^{6}=35,2447-0,399024 \mathrm{CM}\left(\mathrm{r}^{2}=0,80\right) ; \hat{\mathrm{Y}}^{7}=28,5311- \\
0,422427 \mathrm{CM}\left(\mathrm{r}^{2}=0,87\right) ; \hat{\mathrm{Y}}^{8}=5,49893-0,0580589 \mathrm{CM}\left(\mathrm{r}^{2}=0,92\right) .\end{array}$} \\
\hline
\end{tabular}


The contents of these fibrous constituents decreased linearly in both silages, with the addition of increasing levels of cassava meal (Table 3). Reductions of 1.0 and 0.85 and 0.7 and 0.4 percentage units per unit of cassava meal added for the variables NDFap and ADF, without wilting and wilting, respectively were estimated (Table 3 ).

There was significant interaction for cellulose .The effect of wilting showed a difference $(\mathrm{P}<0.05)$ only for silage without cassava meal, presenting a higher value for silage without wilting (Table 3 ). Regarding cellulose contents as a function of cassava meal levels, the regression analysis revealed, for silage without wilting, quadratic behavior, estimating a minimum value of $25.3 \%$ for the level of $20.8 \%$ of cassava meal. For wilting silage, a linear decreasing behavior was observed, estimating reductions of 0.4 percentage unit for each unit of cassava meal added (Table 3). As hemicellulose, cellulose and lignin are constituent of the NDF, reductions of these fractions in the silages were already expected, due to the decreasing behavior of the NDF with the increase of cassava meal levels.
Similar to the results obtained in this study, Silva et al. (2010), Zanine et al. (2010) and Bureenok et al. (2012) also verified reduced NDF content of silage added with cassava scraping. The reduction of the NDF concentration of diets containing a high proportion of forrage can contribute to increase DM intake and, at the same time, increase the energetic density of ruminant feed (JUNG \& ALLEN, 1995).

In relation to hemicellulose and lignin contents, there was an effect $(\mathrm{P}<0.05)$ only of cassava meal. The addition of increasing levels of cassava meal linearly decreased the values of the aforementioned variables (Table 3 ). The cassava starch residues have low levels of NDF, ADF, cellulose and hemicellulose when compared to forage (GONÇALVES et al., 2014).

Similarly, Bonfá et al. (2015), observed a linear reduction of NDF, ADF and cellulose contents, with the addition of passion fruit peel in elephant grass silage.

Regarding the fermentation parameters, significant interaction $(\mathrm{P}<0.05)$ between wilting and cassava meal levels for $\mathrm{pH}$ and N-NH3 of the silages was observed (Table 4).

Table 4. $\mathrm{pH}$ and mean levels of ammoniacal nitrogen (N-NH3) of elephant grass ensiled with and without wilting and cassava meal $(\mathrm{CM})$

\begin{tabular}{|c|c|c|c|c|c|c|c|}
\hline \multirow{2}{*}{ Wilting } & \multicolumn{4}{|c|}{ Cassava meal (\% NM) } & \multirow{2}{*}{ Mean } & \multirow{2}{*}{ CV (\%) } & \multirow{2}{*}{$\begin{array}{c}\text { Regression } \\
\text { equation }\end{array}$} \\
\hline & 0,0 & 7,5 & 15,0 & 22,5 & & & \\
\hline \multicolumn{8}{|c|}{$\mathrm{pH}$} \\
\hline Without & $4,1^{\mathrm{a}}$ & $3,8^{\mathrm{a}}$ & $3,8^{\mathrm{a}}$ & $3,8^{\mathrm{a}}$ & 3,8 & \multirow{3}{*}{0,92} & 1 \\
\hline With & $3,7^{\mathrm{b}}$ & $3,7^{\mathrm{b}}$ & $3,6^{\mathrm{b}}$ & $3,7^{\mathrm{b}}$ & 3,7 & & 2 \\
\hline Mean & 3,9 & 3,7 & 3,7 & 3,7 & & & \\
\hline \multicolumn{8}{|c|}{$\mathrm{N}-\mathrm{NH}_{3}(\% \mathrm{TN})$} \\
\hline Without & $4,9^{\mathrm{a}}$ & $2,7^{\mathrm{a}}$ & $2,5^{\mathrm{a}}$ & $2,6^{\mathrm{a}}$ & 3,2 & \multirow{3}{*}{12,0} & 3 \\
\hline With & $3,5^{\mathrm{b}}$ & $3,0^{\mathrm{a}}$ & $2,5^{\mathrm{a}}$ & $2,5^{\mathrm{a}}$ & 2,8 & & 4 \\
\hline Mean & 4,2 & 2,8 & 2,5 & 2,5 & & & \\
\hline
\end{tabular}

Means followed by the same letter in the same column do not differ from each other by the F-test at 5\% probability; $\hat{\mathrm{Y}} 1=4,09163-0,0399500 \mathrm{CM}+0,00125556 \mathrm{CM}^{2}\left(\mathrm{r}^{2}=0,92\right) ; \hat{\mathrm{Y}}^{2}=3,70537-0,00845000$ $\mathrm{CM}+0,000344444 \mathrm{CM}^{2}\left(\mathrm{r}^{2}=0,99\right) ; \quad \hat{\mathrm{Y}}^{3}=4,82380-0,328975 \mathrm{CM}+0,0104297 \mathrm{CM}^{2}\left(\mathrm{r}^{2}=0,96\right) ; \quad \hat{\mathrm{Y}}^{4}=$ $3,36298-0,0452628 \mathrm{CM}\left(\mathrm{r}^{2}=0,88\right)$. 
Analyzing the wilting effect within cassava meal level, a lower $(\mathrm{P}<0.05) \mathrm{pH}$ value was observed for the silage with wilting. It can be inferred that the reduction in the moisture content of elephant grass concentrated the soluble carbohydrates and increased the osmolarity of the silage that probably promoted reduction in the buffer capacity and accentuated the $\mathrm{pH}$ drop (TAVARES et al., 2009; LYIMO et al., 2016).

Analyzing the $\mathrm{pH}$ in function of the levels of cassava meal, it was observed a quadratic behavior for both silages. For the silage without wilting, a minimum value of 3.7 was estimated for the level of $15.9 \%$ of cassava meal. For the silage with wilting, the estimated minimum value was 3.6 for $12.2 \%$ level of cassava meal (Table 4). The $\mathrm{pH}$ values presented by the silages are compatible with desirable fermentations $(\mathrm{pH}<4.2)$ and can be attributed to the absorbing effect of cassava flour.

In relation to ammoniacal nitrogen $(\mathrm{N}$ $\mathrm{NH} 3$ ), the effect of wilting within the level of manioc meal showed a difference $(\mathrm{P}<0.05)$ in $\mathrm{N}-\mathrm{NH} 3$ value only for the silages without and with wilting, without the addition of cassava meal (Table 4). It can be inferred that the higher content of N-NH3 of the silages without wilting is derived from the biogenesis of amines by enterobacteria which are present in higher quantities in the wetter silage (79\% humidity) and with higher values of $\mathrm{pH}(4,1)$ (DUNIÈRE et al., 2013).

When analyzing the N-NH3 over the levels of cassava meal, regression analysis revealed a quadratic and linear behavior for the silages with and without wilting, respectively, estimating a minimum value of $2.2 \%$ for $15.7 \%$ of cassava meal for the silage without wilting. For the silage with wilting, a decrease of $0.04 \%$ was observed for each unit of cassava meal.

The N-NH3 content is lower than the minimum which is recommended for good quality silages $(\mathrm{N}-\mathrm{NH} 3=10 \% /$ TN) (VAN SOEST, 1994), that is, little protein nitrogen was converted to ammonia by heterofermentative bacteria during the fermentation of the ensiled mass, which directly reflects the final quality of the silages.

For the variables losses of DM by gases and effluent and recovery of DM, there was significant interaction $(\mathrm{P}<0.05)$ between wilting and cassava meal levels. Evaluating the wilting effect within cassava meal levels, higher losses of DM by gases were observed in the silages without wilting (Table 5).

In the study of the effect of cassava meal levels on the losses of DM by gases, an increasing linear behavior was observed for the silages with and without wilting, estimating additions of 0.09 and $0.25 \%$ for each unit of cassava meal (Table 5). Increasing the availability of carbohydrates to microorganisms with the inclusion of cassava meal was probably the factor that led to an increase in losses (MUCK et al., 2010). According to McDonald et al. (1991), energy losses can range from $7 \%$ for well-preserved materials to $40 \%$ for poorly maintained materials. Although the inclusion of cassava meal increased the gas losses, the silage with wilting presented values close to $7 \%$, which is reported as indicative of quality in the fermentation process.

Analyzing the effect of wilting within the cassava meal levels for effluent losses, a difference was observed ( $\mathrm{P}$ $<0.05$ ) only for levels 0 and $7.5 \%$ of cassava meal (Table 5). Regarding the effect of cassava meal levels on effluent losses, the regression analysis revealed a quadratic effect, estimating a minimum value of 10.2 and $6.5 \%$ for the levels of 
18.2 and $16 \%$ of cassava meal, in the silages without and with wilting, respectively. These results allow to infer that the additive used allowed to reduce the losses by effluents, which is explained by the absorbent characteristic $(85.1 \% \mathrm{DM})$ of the additive used. Zanine et al. (2010) also verified reduction in effluent losses in elephant grass silages with the addition of cassava scrapings.

Table 5. Gas, effluent losses and dry matter recovery of elephant grass ensiled with and without wilting and cassava meal $(\mathrm{CM})$

\begin{tabular}{|c|c|c|c|c|c|c|c|}
\hline \multirow{2}{*}{ Wilting } & \multicolumn{4}{|c|}{ Cassava meal (\% NM) } & \multirow{2}{*}{ Mean } & \multirow{2}{*}{ CV $(\%)$} & \multirow{2}{*}{$\begin{array}{c}\text { Regression } \\
\text { equation }\end{array}$} \\
\hline & 0,0 & 7,5 & 15,0 & 22,5 & & & \\
\hline \multicolumn{8}{|c|}{ Gas ( \% MS ) } \\
\hline Without & $7,8^{\mathrm{a}}$ & $8,0^{\mathrm{a}}$ & $9,6^{\mathrm{a}}$ & $9,6^{\mathrm{a}}$ & 8,7 & \multirow{2}{*}{14,5} & 1 \\
\hline With & $1,3^{\mathrm{b}}$ & $5,4^{\mathrm{b}}$ & $6,6^{\mathrm{b}}$ & $7,2^{\mathrm{b}}$ & 5,2 & & 2 \\
\hline Mean & 4,5 & 6,7 & 8,1 & 8,4 & - & - & - \\
\hline \multicolumn{8}{|c|}{ Effluent (Kg/t NM) } \\
\hline Without & $76,4^{\mathrm{a}}$ & $31,1^{\mathrm{a}}$ & $14,0^{\mathrm{a}}$ & $13,3^{\mathrm{a}}$ & 33,7 & \multirow{2}{*}{18,3} & 3 \\
\hline With & $22,0^{\mathrm{b}}$ & $9,2^{\mathrm{b}}$ & $8,2^{\mathrm{a}}$ & $8,6^{\mathrm{a}}$ & 12,0 & & 4 \\
\hline \multirow[t]{2}{*}{ Mean } & 49,2 & 20,2 & 11,0 & 10,9 & - & - & - \\
\hline & \multicolumn{4}{|c|}{ DM Recovery ( \% MS ) } & & \multirow{3}{*}{2,1} & \\
\hline Without & $84,4^{\mathrm{a}}$ & $88,4^{\mathrm{a}}$ & $79,8^{b}$ & $83,0^{b}$ & 87,0 & & 5 \\
\hline With & $84,5^{\mathrm{a}}$ & $88,8^{\mathrm{a}}$ & $91,2^{\mathrm{a}}$ & $91,9^{\mathrm{a}}$ & 89,1 & & 6 \\
\hline Mean & 90,8 & 88,6 & 85,5 & 87,4 & - & - & - \\
\hline
\end{tabular}

Means followed by the same letter in the same column do not differ from each other by the F-test at 5\% probability; $\hat{\mathrm{Y}} 1=7,70042+0,0942902 \mathrm{CM}\left(\mathrm{r}^{2}=0,88\right) ; \hat{\mathrm{Y}} 2=2,33003+0,251748 \mathrm{CM}\left(\mathrm{r}^{2}=0,98\right) ; \hat{\mathrm{Y}} 3=$ $75,8741-7,2160 \mathrm{CM}+0,1982 \mathrm{CM}^{2}\left(\mathrm{r}^{2}=0,99\right) ; \hat{\mathrm{Y}} 4=21,5046-1,877833 \mathrm{CM}+0,0587546 \mathrm{CM}^{2}\left(\mathrm{r}^{2}=\right.$ $0,96) ; \hat{\mathrm{Y}} 5=86,5 ; \hat{\mathrm{Y}} 6=85,4175+0,3306 \mathrm{CM}\left(\mathrm{r}^{2}=0,99\right)$.

The silage effluent contains large amounts of organic compounds, such as sugars, organic acids and proteins, leading to significant losses of nutritive value (McDONALD et al., 1991). In addition, silage effluents present high biological demand for oxygen and can cause eutrophication (GEBREHANNA et al., 2014).

Regarding the recovery of DM, when evaluating the wilting effect within the levels of cassava meal, a difference ( $P$ $<0.05)$ was observed for levels of 15 and $22.5 \%$ of cassava meal. Through the regression analysis, studying the recovery of DM for the silages without wilting, it was observed that it was not influenced by the levels of cassava meal, with a mean value of $86.5 \%$. Regarding silage with wilting, there is an increasing linear behavior with the increase of cassava meal levels, estimating increases of 0.3 percentage units for each unit of cassava meal. Considering that the higher gas and effluent referred to silage with wilting, probably this fact explains the lower rates of MS recovery of the aforementioned silages. Concerning the silage with wilting, it can be verified that the addition of cassava meal provided higher DM recovery rates,

In situations where the practice of wilting is viable, it should be adopted since it proides silages with higher DM and $\mathrm{CP}$ contents and better fermentative characteristics. The addition of $\mathrm{CM}$ to the elephant grass with or without wilting up to the dosage of $22.5 \% \mathrm{NM}$ improves the nutritive value of the silage and provides greater DM recovery of of the silage from the wilted elephant grass. 


\section{REFERENCES}

ANDRADE, I.V.O.; PIRES, A.J.V.; CARVALHO, G.G.P.; VELOSO, C.M.; BONOMO, P. Fracionamento de proteína e carboidratos em silagens de capimelefante contendo subprodutos agrícolas.

Revista Brasileira de Zootecnia, v.39, n.11, p.2342-2348, 2010.

BACH, A.; CALSAMIGLIA, S.; STERN, M.D. Nitrogen Metabolism in the Rumen. Journal of Dairy Science, v.88, p.9-21, 2005. Sup1.

BONFÁ, C.S.; CASTRO, G.H.F.; VILLELA, S.D.J.; SANTOS, R.A.; EVANGELISTA, A.R.; JAYME, C.G.; GONÇALVES, L.C.; PIRES NETO, O.S.; BARBOSA, J.A.S. Silagem de capimelefante adicionada de casca de maracujá. Arquivo Brasileiro de Medicina Veterinária e Zootecnia, v.67, n.3, p.801808, 2015.

BUREENOK, S.; YUANGKLANG, C.; VASUPEN, K.; SCHONEWILLE, J.T.; KAWAMOTO, Y. The effects of additives in napier grass silages on chemical composition, feed intale, nutrient digestibility and rumen fermentation.

Asian-Australasian Journal of Animal Science, v.25, n.9, p.1248-1254, 2012.

CUNNIFF, P. Official methods of analysis of AOAC International. 16 ed. Arlington: AOAC International, 1995. v.1.

DÓREA, J.R.R.; OLIVEIRA, J.S.; SANTOS, E.M.; ZANINE, A.M.; SILVA, T.C.; DANÉS, M.A.C.; FRANCO, A.L.C.; GOUVÊA, V.N.; MIZUBUTI, I.Y. Cinética de degradação ruminal de silagem de capim-elefante com diferentes níveis de jaca e raspa de mandioca.

Semina:Ciências Agrárias, v.34, n.5, p.2437-2446, 2013.
DUNIÈRE, L.; SINDOU, J.; CHAUCHEYRAS-DURAND, F.; CHEVALLIER, I.; THÉVENOTSERGENTET, D. Silage processing and strategies to prevent persistence of undesirable microorganisms. Animal Feed Science and Technology, v.182, n.1-4, p.1-15, 2013.

EMPRESA BRASILEIRA DE PESQUISA AGROPECUÁRIA. EMBRAPA. Sistema brasileiro de classificação de solos. 2.ed. Rio de Janeiro: EMBRAPA/Centro Nacional de Pesquisa de Solos, 2006. 306p.

GEBREHANNA, M.M.; GORDON, R.J.; MADANI, A.; VANDERZAAG, A.C.; WOOD, J.D. Silage effluent management: A review. Journal of Environmental Management, v.143, n.1, p.113-122, 2014.

GONÇALVES, J.A.G.; ZAMBOM, M.A.; FERNANDES, T.; MESQUITA, E.E.; SCHIMIDT, E.; JAVORSKI, C.R.; CASTAGNARA, D.D. Composição químico-bromatológica e perfil de fermentação da silagem de resíduo úmido de fécula de mandioca. Bioscince Journal, v.30, n.2, p. 502-511, 2014.

JUNG, H.G.; ALLEN, M.S.

Characteristics of plant cell walls affecting intake and digestibility of forages by ruminants. Journal of Animal Science, v.73, n.9, p.2774-2790, 1995.

LYIMO, B.J.; MTENGETI, E.J.; URIO, N.A.; NDEMANISHO, E.E. Effect of fodder grass species, wilting and ensiled amount in shopping plastic bags on silage quality. Livestock Research for Rural Development, v.28, n.8, 2016. 
MAZA, A.L.; VERGARA, G.O.; PATERNINA, D.E. Evaluación química y organoléptica del ensilaje de maralfalfa (Pennisetum sp.) más yuca fresca (Manihot esculenta). Revista Medicina Veterinaria e Zootecnia, v.16, n.2, p.2528-2537, 2011.

McDONALD, P.; HENDERSON, A.R.; HERON, S. The biochemistry of silage. 2.ed. Marlow: Chalcombe Publications, 1991.340p.

MUCK, R.E. Silage microbiology and its control through additives. Revista

Brasileira de Zootecnia, v.39, p.183-191, 2010.

NAPASIRTH, V.; NAPASIRTH, P.; SULINTHONE, T.; PHOMMACHANH, K.; CAI, Y. Microbial population, chemical composition and silage fermentation of cassava residues. Animal Science Journal, v.86, n.3, p.842-848, 2015.

NATIONAL RESEARCH COUNCIL NRC. Nutrient requirements of dairy cattle. 7.ed. Washington: National Academy Press, 2001. 450p.

ODUGUWA, B.O.; ONI, A.O.; MOSES, O.; ADESUNBOLA, J.O.; SUDEKUM,

K.H. Feeding potential of cassava (Manihot esculenta Crantz) peels ensiled with Leucaena leucocephala and Gliricidia sepium assessed with West African dwarf goats. Tropical Animal Health and Production, v.45, p.1363-1368, 2013.

OLIVEIRA, A.C.; GARCIA, R.; PIRES, A.J.V.; OLIVEIRA, H.C.; ALMEIDA, V.V.S.; VELOSO, C.M.; ROCHA NETO, A.L.; OLIVEIRA, U.L. C. Farelo de mandioca na ensilagem de capim-elefante: fracionamento de carboidratos e proteínas e características fermentativas. Revista Brasileira de Saúde e Produção Animal [online], v.13, n.4, p.1020-1031, 2012.
PELL, A.N.; SCHOFIELD, P. Computerized monitoring of gas production to measure forage digestion in vitro. Journal of Dairy Science, v.76, n.9, p.1063-1073, 1993.

PINHO, R.M.A.; SANTOS, E.M.; CARVALHO, G.G.P.; SILVA, A.P.G.; SILVA, T.C.; CAMPOS, F.S.; MACEDO, C.H.O. Microbial and fermentation profiles, losses and chemical composition of silages of buffel grass harvested at different cutting heights. Revista Brasileira de Zootecnia, v.42, n.12, p.850-856, 2013.

RIBEIRO, L.S.O.; PIRES, A.J.V.; CARVALHO, G.G.P.; PEREIRA, M.L.A.; SANTOS, A.B.; ROCHA, L.C. Características fermentativas, composição química e fracionamento de carboidratos e proteínas de silagem de capim-elefante emurchecido ou com adição de torta de mamona. Semina: Ciências Agrárias, v.35, n.3, p.1447-1462, 2014.

RIGUEIRA, J.P.S.; PEREIRA, O.G.; RIBEIRO, K.G.; MANTOVANI, H.C.; AGARUSSI, M.C.N. The chemical composition, fermentation profile, and microbial populations in tropical grass silages. Revista Brasileira de Zootecnia, v.42, n.9, p.612-621, 2013.

SANTOS, M.C.; NUSSIO, L.G.; MOURÃO, G.B; SCHMIDT, P.; MARI, L.J.; RIBEIRO, J.L. Influência da utilização de aditivos químicos no perfil da fermentação, no valor nutritivo e nas perdas de silagens de cana-de-açúcar.

Revista Brasileira de Zootecnia, v.37, n.9, p.1555-1563, 2008.

SANTOS, R.J.C.; LIRA, M.A.; GUIM, A.; SANTOS, M.V.F.; DUBEUX JUNIOR, J.C.B.; MELLO, A.C.L. Elephant grass clones for silage production. Scientia Agricola, v.70, n.1, p.6-11, 2013. 
STATISTICAL ANALYSES SYSTEM. SAS: user's guide. Cary: 1999. v.8, 295p.

\section{SILVA, A.M.; OLIVEIRA, R.L.;} RIBEIRO, O.L.; BAGALDO, A.R.; BEZERRA, L.R.; CARVALHO, S.T.; ABREU, C.L.; LEÃO, A.G. Valor nutricional de resíduos da agroindústria para alimentação de ruminantes.

Comunicata Scientiae, v.5, n.4, p.370379, 2014.

SILVA, C.F.P.G.; PEDREIRA, M.S.; FIGUEIREDO, M.P.; BERNARDINO, F.S.; FARIAS, D.H. Qualidade fermentativa e caracterização químicobromatológica de silagens da parte aérea e raízes de mandioca (Manihot esculenta Crantz). Acta Scientiarum. Animal Science, v.32, n.4, p.401-408, 2010.

SILVA, D.J., QUEIROZ, A.C. Análise de alimentos: métodos químicos e biológicos. Viçosa, MG: Universidade Federal de Viçosa, 2002. 235p.

TAVARES, V.B.; PINTO, J.C.; EVANGELISTA, A.R.; FIGUEIREDO, H.C.P.; ÁVILA, C.L.S.; LIMA, R.F. Efeitos da compactação, da inclusão de aditivo absorvente e do emurchecimento na composição bromatológica de silagens de capim-tanzânia. Revista Brasileira de Zootecnia, v.38, n.1, p.40-49, 2009.

Van SOEST, P.J.; ROBERTSON, J.B.; LEWIS, B.A. Methods for dietary fiber, neutral detergent fiber, and nonstarch polysaccharides in relation to animal nutrition. Journal of Dairy Science, v.74, n.10, p.3583-3597, 1991.

WEISS, W.P.; CONRAD, H.R.; PIERRE, N.R. St. A theoretically-based model for predicting total digestible nutrient values of forages and concentrates. Animal Feed Science and Technology, v.39, p.95-110, 1992.
ZANINE, A.M.; SANTOS, E.M.; DÓREA, J.R.R.; DANTAS, P.A.S.; SILVA, T.C.; PEREIRA, O. G. Evaluation of elephant grass silage with the addition of cassava scrapings.

Revista Brasileira de Zootecnia, v.39, n.12, p.2611-2616, 2010.

Data de recebimento: 09/11/2016 Data de aprovação: 12/06/2017 